\title{
Pajak E-Commerce, Pemecahan dan Solusinya
}

Ajat Sudrajat ${ }^{1}$

${ }^{1}$ Institut Ilmu Sosial dan Manajemen STIAMI, Jakarta, Indonesia

Email;:Sudrajat.gagnikel@gmail.com

\section{ARTICLE INFO}

\section{Keywords}

tax, e-commerce, the solution

of solving the problem

\begin{abstract}
Electronic or e-trade trading (English: Electronic Commerce, also ecommerce) is a spread, purchase, sales, marketing goods and services through an electronic system such as internet or television, www, or other computer networks. Ecommerce can involve electronic fund transfers, electronic data exchange, auto inventory management systems, and automatic data collection systems. The Information Technology industry sees this e-commerce activity as the application and application of e-business (e-business) related to commercial transactions, such as: electronic fund transfer, SCM (EMarketing), e-marketing), online marketing, online transaction processing (online transaction processing), electronic data interchange / edi), etc.Ecommerce is part of e-business, where e-business coverage is wider, not just a commerce but includes also co-entrance business partners, customer service, job vacancies etc.
\end{abstract}

Seeing very fast developments of the e-commerce growth in the world including in Indonesia, it is necessary an effective strategy for the tax authority in the reacting. One of the things that need to be concern is this very rapid growth should be maintained so that there is no distortion as a result of taxation policy. During this time, the tax aspect in e-commerce has been the highlight of tax authorities in the world, especially whether there should be a new tax impression on this transaction and also how to align the existing tax rules with e-commerce development.Transactions through digital media or e-commerce in Indonesia need rebuilding from the side of the legislation (Cyberlaw) so that in the future do not miss the dispute in it runs. This happens because the difficulty of tracking the transactions used through the e-commerece is either B-to-B (business to business) or B-to-C (business to consumers). For example the relationship between the supplier with the factory, how the apparatus is to oversee the existence of transactions or not between the two through the ecommerce

the solution of solving the problem is the government must take steps in solving the unstable internet infrastructure issues and frequent reliable transportation, the licensing procedure of customs to dedicate to the duty procedure from dawn to the negative trade for the other value to increase the efficacy to make the rules for the epimal services that are still under the regulations of the same bank as well as the public of the transactions of online transactions, plan and conduct the introduction of certification systems, a number of large players should be able to open the way of foreign investment, including doing some major plans for foreign investors, of course with clear regulations and the government must provide ease of rules for small and medium business to gain access to investors, and giving taxes to the company in the new company.

\section{Pendahuluan}

Memasuki era millenium ke-3, perkembangan jaman berkembang sangat cepat dan telah melahirkan perkembangan teknologi informasi yang semakin pesat, sehingga berdampak terhadap perubahan tatanan aspek kehidupan, mulai dari aspek ekonomi, bisnis, politik, sosial kemasyarakatan, transformasi, komunikasi, informasi dan lain-lain. Pesatnya perekembangan dunia teknologi informasi tersebut tak lepas dari pesatnya perkembangan teknologi internet yang merambah hampir seluruh belahan dunia.

Internet adalah jaringan komputer terbesar di dunia pada saat ini digunakan oleh berjuta-juta orang yang tersebar di dunia. Teknologi internet mempunyai pengaruh yang sangat besar terhadap perekonomian dunia. Makin banyak kegiatan perekonomian dilakukan menggunakan media internet. Perdagangan misalnya, semakin banyak mengandalkan e-commerce sebagai media transaksi dan khususnya di bidang perpajakan. Perkembangan yang pesat dalam bidang teknologi di berbagai sektor juga membawa dampak 
kepada perkembangan di dunia usaha. Hal ini bisa disimak dari kegiatan usaha melalui e-commerce, sebagai hasil dari kemajuan di sektor komunikasi dan teknologi informasi.

\section{Pengertian E- Commerce}

Ada banyak definisi untuk e-commerce, tapi yang pasti, e-commerce merujuk pada semua bentuk transaksi komersial yang menyangkut organisasi dan individu yang didasarkan pada pemrosesan dan transmisi data yang digitalisasikan, termasuk teks, suara dan gambar. Termasuk juga pengaruh bahwa pertukaran informasi komersial secara elektronik yang mungkin terjadi antara institusi pendukungnya dan aktivitas komersial pemerintah. Ini termasuk antara lain manajemen organisasi, negosiasi dan kontrak komersial, legal dan kerangka regulasi, penyusunan perjanjian keuangan, dan pajak satu sama lain.

Electronic Commerce (Perniagaan Elektronik), sebagai bagian dari Electronic Business (bisnis yang dilakukan dengan menggunakan electronic transmission), oleh para ahli dan pelaku bisnis dicoba dirumuskan definisinya. Secara umum e-commerce dapat didefinisikan sebagai segala bentuk transaksi perdagangan atau perniagaan barang atau jasa (trade of goods and service) dengan menggunakan media elektronik.

Menurut Laudon \& Laudon (1998), e-commerce adalah suatu proses membeli dan menjual produkproduk secara elektronik oleh konsumen dan dari perusahaan ke perusahaan dengan komputer sebagai perantara transaksi bisnis.

E-commerce digunakan sebagai transaksi bisnis antara perusahaan yang satu dengan perusahaan yang lain, antara perusahaan dengan pelanggan (customer), atau antara perusahaan dengan institusi yang bergerak dalam pelayanan publik. Sasaran e-commerce adalah menciptakan lingkungan komersial yang baru dalam segala bentuknya di abad elektronik. Di mana beberapa tahap yang umumnya terdapat diantara penjual dan pembeli dalam transaksi komersial dapat diintegrasikan sekaligus dan otomatis secara elektronik. Jadi dapat meminimalkan biaya transaksi.

\section{Jenis E- Commerce}

Menurut Turban \& Volonino (2010:201), Aplikasi E-Commerce didukung oleh infrastruktur yang meliputi peranti keras, peranti lunak dan jaringan berkisar dari penjelajah hingga multimedia dan juga berdasarkan lima area pendukung berikut ini

a. Orang : yaitu para penjual, pembeli, perantara, ahli system informasi dan karyawan lainnya, serta peserta lainnya

b. Kebijakan publik : terdapat berbagai isu hukum dan kebijakan serta peraturan lainnya seperti perlindungan atas privasi dan perpajakan, yang ditetapkan oleh pemerintah

c. Pemasaran dan periklanan : e-commerce biasanya membutuhkan dukungan pemasaran dan periklanan seperti juga bisnis lainnya. Ini sangat penting terutama dalam transaksi online B2C yang pembeli dan penjualnya biasanya tidak saling mengenal

d. Layanan pendukung : berbagai layanan dari pembayaran hingga pengiriman pesanan serta pembuatan isi dibutuhkan untuk mendukung EC

e. Kemitraan bisnis : usaha bersama, pasar elektronik, dan kemitraan bisnis adalah hal yang umum dalam EC. Hal ini seringkali terjadi di sepanjang rantai pasokan (yaitu interaksi antara perusahaan dengan para pemasoknya, pelanggannya, dan dengan mitra lainnya).

Masih menurut Turban \& Volonino (2010), ada dua jenis e-commerce, yaitu :

1. Front-end e-commerce,

Front-end-commerce yaitu transaksi melalui e-commerce antara pengusaha (baik pribadi maupun badan hukum) dengan konsumen.

2. Back-end e-commerce,

Back-end-commerce yaitu transaksi antara para pengusaha menyangkut transaksi informasi internal dengan masing-masing pengusaha atau antara para pelaku usaha menyangkut pertukaran data komersial.

\section{Kerumitan Kegiatan E-Commerce}

Kegiatan usaha e-commerce dapat dilakukan melalui apa yang disebut Application Service Provider (ASP) yang biasanya menjadi sarana utama bagi pelaku usaha di bidang ini. ASP menyediakan disk space untuk disewa pengusaha untuk menawarkan produksinya.

Disk space tersebut tidak dapat dipergunakan tanpa dilengkapi dengan program tertentu (dalam bentuk software) sehingga space tersebut menjadi website. Pemilik ASP biasanya menyewakan space yang dimilikinya kepada perusahaan-perusahaan tertentu yang selanjutnya akan menggunakannya sebagai 
website-nya. Perusahaan yang menyewa space dimaksud kemudian mengisinya dengan perangkat lunak yang dapat diakses oleh para calon pembeli. Dari website tersebut maka perusahaan dimaksud menawarkan barang produksinya. Perlakuan pajak penghasilan terhadap transaksi bisnis tersebut akan dibahas pada makalah ini dengan mengambil asumsi pertama bahwa ASP dimaksud berada di Indonesia.

Berbeda dengan transaksi perdagangan biasa, transaksi e-commerce memiliki beberapa karakteristik yang sangat khusus sehingga mengakibatkan implikasi pajak yang agak rumit dari kegiatan tersebut. Hal ini terjadi karena Transaksi elektronik antara e-merchant (pihak yang menawarkan barang atau jasa melalui internet) dengan e-customer, (pihak yang membeli barang atau jasa melalui internet) yang terjadi di dunia maya atau di internet pada umumnya berlangsung secara paperless transaction, sedangkan dokumen yang digunakan dalam transaksi tersebut bukanlah paper document, melainkan dokumen elektronik (digital document). Transaksi tersebut bisa melalui chatting, video conference atau melalui e-mail. Kontrak melalui $e$-mail adalah salah satu kontrak on line yang sangat populer karena pengguna e-mail saat ini sangat banyak dan mendunia dengan biaya yang sangat murah dan waktu yang efisien. Di samping itu kontrak e-mail dapat dilakukan dengan penawaran barangnya diberikan atau diserahkan melalui situs web yang memposting penawarannya, sedangkan penerimaannya dilakukan melalui e-mail.

Kontrak melalui web dapat dilakukan dengan cara situs web seorang supplier (baik yang berlokasi di server supplier maupun diletakkan pada server pihak ketiga) memiliki diskripsi produk atau jasa dan satu seri halaman yang bersifat self-contraction, yaitu dapat digunakan untuk membuat kontrak sendiri, yang memungkinkan pengunjung web untuk memesan produk atau jasa tersebut. Para konsumen harus menyediakan informasi personal dan harus menyertakan nomor kartu kredit.

Untuk produk on line yang berupa software, pembeli atau konsumen diizinkan untuk men-downloadnya. Untuk produk yang berwujud fisik, pengiriman barang dilakukan sampai di tempat konsumen dan untuk pembelian jasa, supplier menyediakan untuk melayani konsumen sesuai dengan waktu dan tempat yang telah ditentukan dalam perjanjian. Selanjutnya cara pembayaran dapat dilakukan melalui transaksi model ATM, pembayaran langsung tanpa perantara, melalui perantara pihak ketiga, dengan micropayment dan ADC (Anonymous Digital Cash).

Proses e-commerce sendiri terutama ditujukan untuk mengeffisienkan transaksi dokumen khususnya dokumen pada transaksi pembayaran melalui e-payment, yang pada akhirnya akan mengeffisienkan transaksi barang. Masalah hukum (legal) e-commerce menjadi menarik dan tentu "kompleks" karena dokumen dibuat di PC, di mana index di PC, digunakan dalam bentuk kertas (biasanya), di simpan dan di arsip ke dalam bentuk kertas atau elektronik. Revolusi e-bisnis mengembangkan proses bisnis yang baru, terlalu banyak informasi, kertas tidak bisa diterima, bergerak dengan sangat cepat, akan tetapi harus ada pergeseran paradigma yang membutuhkan penerimaan, perubahan hukum, cara atau prosedur yang baru, pola pikir yang baru dan terutama membutuhkan pemikiran yang bersih. Inisiatif Electronic Original mengusulkan beberapa langkah taktis terdiri dari lima (5) kesepakatan internasional untuk melakukan $e$-commerce yang baik, mulai dari penyimpanan informasi secara elektronik, kebijakan menggunakan e-mail untuk berkomunikasi, indentitas, tanda tangan digital dan hak cipta, penggunaan certificate authority dan penggunaan kepercayaan pihak ke tiga. Langkah selanjutnya adalah Kebijakan untuk keamanan informasi, analisa resiko, infrastruktur keamanan yang mendukung transaksi e-commerce dan e-dokumen.

\section{Masalah E- Commerce}

Melihat potensi perkembangan kegiatan usaha e-commerce membuat perusahaaan-perusahaan menjalankan strategi barunya untuk memasuki dunia internet namun bagaimana perhitungan pajak untuk masalah ini? Menurut William Fox dan Donald Bruce (2009), e-commerce telah menyebabkan dua kehilangan pajak sekaligus. Pertama, e-commerce merupakan pengganti dan perluasan dari remote sales yang pajaknya tidak pernah dikumpulkan. Kedua, e-commerce yang merupakan subtitusi atau perluasan juga tidak terjangkau oleh peraturan pajak atau retribusi lokal, sekalipun yang terbaru. Inilah yang ditunding mengapa banyak pemerintah melihat e-commerce sebagai salah satu penyebab terbesar hilangnya penerimaan negara yang amat signifikan. Tidak heran bila atas nama defisit, sejak berapa tahun sebelumnya, pemerintah Federal Amerika mulai untuk memberlakukan pajak atas e-commerce atau e-trading. Proyek ini dikenal dengan nama Streamlined Sales Tax Project (SSTP). Menurut Alisa Shelton, SSTP ini berbenturan dengan keputusan Mahkamah Agung Amerika yang menyebutkan secara jelas bahwa internet dan catalogue merchants tidak dapat dipungut pajak penjualannya. Karena, keduanya tidak memenuhi syarat kehadiran fisik (Nexus) dalam setiap negara bagian para pelanggannya. Tentu saja hal ini membuat para pedagang internet dan katalog bersemangat, karena daya saingnya kian menguat. Itu juga sebabnya, perdagangan dengan kedua moda tersebut kini semakin marak dilakukan. Seperti pernyataan Mahkamah Agung Amerika 
dengan mengajukan Internet Tax Freedom Act yang ternyata sangat disetujui oleh Senat Amerika Serikat, undang-undang ini melarang semua negara bagian dan lokal di Amerika untuk memajak informasi \& perdagangan melalui Internet.

Yang lebih menarik lagi adalah pada dekade sebelumnya, Kongres Amerika meluluskan Internet Tax Free Act (ITFA). Akta ini sebenarnya mengatur moratorium selama 3 tahun dalam pemberlakuan pajak penjualan, termasuk yang berbasiskan internet. Namun, bersamaan dengan hampir berakhirnya masa tersebut, kemampuan pemerintah federal atau lokal dalam melakukan pungutan pajak sesuai dengan regulasi yang ada, ternyata juga tidak berubah. Prof. Fox dan Bruce, seorang pak ar ekonomi mengakui bahwa internet sebagai salah satu faktor dari kehilangan pendapatan pemerintah, namun perdagangan antar perusahaan $(B-$ to-B, Business to Business) ditunding bertanggung jawab atas hilangnya $75 \%$ dari potensi penerimaan pajak pemerintah lokal dan federal. Dari hal tersebut diketahui bahwa diperlukan sebuah mekanisme pajak yang efisien untuk menangani masalah tersebut.

\section{Perkembangan E-Commerce Menimbulkan Permasalahan Perpajakan}

Menurut Nufransa (2001), melihat perkembangan yang sangat cepat dari pertumbuhan e-commerce di dunia termasuk di Indonesia, maka diperlukan suatu strategi yang efektif bagi otoritas perpajakan dalam menyikapinya. Salah satu hal yang perlu menjadi perhatian adalah pertumbuhan yang sangat pesat ini harus tetap dijaga agar tidak terjadi distorsi sebagai akibat kebijakan perpajakan. Selama ini, aspek perpajakan dalam e-commerce telah menjadi sorotan otoritas perpajakan di dunia, terutama apakah harus ada pengenaan pajak baru terhadap transaksi ini dan juga bagaimana menyelaraskan peraturan perpajakan yang ada dengan perkembangan e-commerce.

Berkembangnya kegiatan usaha e-commerce ternyata berhasil menggerakan roda perekonomian sebuah negara. Transaksi-transaksi yang terjadi memang sangat menggiurkan. Itu sebabnya muncul efek bola salju, sehingga menarik minat pebisnis lainnya untuk mendayagunakan internet sebagai jalur pemasaran baru. Internet memungkinkan sebuah perusahaan kecil dan menangah untuk bersaing dengan perusahaan besar lainnya dan meraih peluang di pasar global. Daya tarik lain e-commerce adalah jangkauan pasar yang tidak lagi terbatas pada sejumlah daerah atau dalam sebuah negara, tetapi seluruh dunia. Ini tentunya yang membuat sebuah perusahaan kecil potensial mendunia sama dengan perusahaan transnasional.

Booming e-commerce ternyata tidak hanya menarik minat kalangan bisnis, melainkan juga kalangan pemerintah. Ketertarikan kalangan pemerintah ternyata memiliki ambiguitas. Di satu sisi, sejumlah pemerintah menyadari sekali peran pentingnya e-commerce dalam lingkungan bisnis di era informasi saat ini. Sehingga banyak dari pemerintahan di dunia saat ini yang mendorong pertumbuhan e-commerce dalam lingkungannya masing-masing. Di sisi lain, pemerintah mulai juga menimbang-nimbang untuk memberlakukan pajak atas e-commerce guna menutupi defisit anggaran belanjanya.

Beberapa kalangan pemerintah, terutama pemerintah negara bagian di Amerika Serikat menuding bahwa e-commerce merupakan salah satu biang penurunan perolehan pajak selama ini. Bahkan, kalangan pemerintah negara bagian Amerika Serikat menyingkirkan remote atau postal trading yang lazim dikenal di sana. Mereka melihat pertumbuhan e-ommerce atau e-business sebagai penggeser remote sales. Sehingga beberapa tahun sebelumnya pemerintah Amerika Serikat memberlakukan pajak melalui Streamlined Sales Tax Project (SSTP).

Memberlakukan pajak internet ternyata tidak semudah yang dibayangkan banyak orang. Berdasarkan survei beberapa tahun lalu terungkap sekitar $85 \%$ perusahaan kecil dan menengah di Amerika menggunakan internet. Dari jumlah tersebut hanya $23 \%$ perusahaan tersebut yang mengimplementasikan e-commerce. Survei juga mengungkapkan sekitar 53\% perusahaan yang memiliki web page, namun $42 \%$ justru memberi jawaban bahwa internet tidak berdampak apapun terhadap bisnisnya. Kendala untuk menerapkan $e$ commerce adalah waktu untuk merencanakan dan kemudian menerapkannya, pembaruan teknologi, biaya untuk mengimplementasikan dan terbatasnya keahlian teknologi yang dimilikinya.

Model bisnis atau usaha berbasis e-commerce sangat berbeda dengan bisnis konvensional. Amazon misalnya, hanya memiliki kantor pusat tapi tidak memiliki outlet secara fisik. Beda dengan toko buku konvensional yang memiliki outlet di banyak tempat untuk menjangkau pasar yang diincarnya. Untuk berbisnis seperti layaknya sebuah jaringan ritel, pelaku e-commerce bisa menikmati jaringan kerja yang ada. Ini berarti melibatkan pihak ketiga yang mendukung terselenggaranya jaringan tersebut. Proses pembelian bisa dilakukan secara online, tapi pengiriman dilakukan secara offline.

Model lain dari e-commerce adalah produk dan jasa yang diubah bentuknya dalam format digital (digitized), umumnya berupa artikel, buku, lagu dan sebagainya dan dihantarkan baik untuk perusahaan lain maupun end-user. Model ini lebih sulit untuk direka-ulang dari mana tujuannya dan ke mana disampaikan. Artinya, 
diperlukan cara pembuktian yang lebih dari sekedar cara-cara konvesional yang sudah ada. Akibatnya, produk dan jasa yang didigitized tidak hanya rawan penggelapan, tapi juga sulit untuk dikenakan jenis pajak apapun.

Namun, sejumlah pemerintah yang jeli sudah memberlakukan pajak penjualan atau pertambahan nilai (Value Added Tax) terhadap setiap transaksi e-commerce yang terjadi. Uni Eropa, misalnya, memberlakukan pajak pertambahan nilai (PPN) pada setiap produk yang bersifat downloadable, yang dihantarkan ke institusi bisnis atau pengguna akhir. Namun, hal itu tidak berlaku di seluruh kawasan Eropa. Di Jerman, penyedia lokal akan memungut pajak konsumsi atas setiap produk software yang di-download di dalam negeri. Pengenaan pajak, pada satu sisi, ternyata bisa berakibat melorotnya daya saing produk atau jasa serupa terhadap kompetitornya di luar negeri. Tentu hal ini dianggap merugikan para pelaku bisnis yang berbasis di Eropa. Itu sebabnya, Uni Eropa terus membahas lebih lanjut langkah-langkah pemberharuan penerapan pajak atas e-commerce di seluruh kawasan Eropa. India dan Filipina tampaknya juga sudah mempertimbangkan secara serius kebijakan pajak e-commerce di masa depan. India merupakan salah satu calon raksasa teknologi informasi (TI) yang banyak mengekspor produk dan jasa e-commerce. Kebanyakan dari produk dan jasa tersebut selama ini tidak dikenakan pajak, sehingga negara dirugikan dari sisi penerimaannya. Bila itu terjadi terus-menerus maka jelas negara akan kehilangan potensi penerimaan yang sangat signifikan di masa depan.

\section{Cyberlaw dan Pengenaan Pajak pada E-Commerce}

Transaksi melalui media digital atau e-commerce di Indonesia perlu pembenahan dari sisi perundangan (CyberLaw) agar di kemudian hari tidak tejadi perselisihan dalam menjalankannya. Hal ini terjadi karena sulitnya melacak transaksi yang digunakan lewat e-commerece baik itu B-to-B (bisnis ke bisnis) atau B-to-C (bisnis to konsumen). Misalnya hubungan antara pemasok dengan pabrik, bagaimana aparat mengawasi telah ada transaksi atau belum antar keduanya lewat e-commerce tersebut (Nurfansa, 2001)

Di antara anggota-anggota Asean sendiri, sudah terbentuk e-Asean untuk menggalang kerjasama lebih erat dalam bidang TI. Setiap negara diwakili oleh 2 orang, terdiri atas swasta dan pemerintah. Sebagaimana diketahui hukum positif di Indonesia masih bersifat lex loci delicti yang mencakup wilayah, barang bukti, tempat atau fisik kejadian serta tindakan fisik yang terjadi. Padahal, kondisi pelanggaran yang mungkin terjadi di cyberspace dapat dikatakan sangat bertentangan dengan hukum positif yang ada tersebut. Pelanggaran itu seperti pada beberapa titik rawan pada cyberspace yang mungkin dapat terjadi yakni pada aspek legal home page, HKI produk multimedia, HKI software (perangkat lunak), aspek hukum e-commerce, perlindungan nama domain internet, badan pengawas internet, privasi pada cyberspace, hukum kontrak via internet, perlindungan informasi kesehatan dalam telemedicine, HKI dalam distance learning, hak ekonomi dalam hak cipta, hak cipta untuk perpustakaan, penggunaan kriptografi dan digital signature untuk transaksi elektronis, hukum pornografi pada internet, aspek hukum pada transaksi digital, dan pajak pada internet.

Keberadaan e-commerce saat ini, memang begitu rentan dari masalah kejahatan pembobolan, apalagi saat ini sedang marak - maraknya. Aksi para hacker yang biasa melakukan ini juga telah sangat mengganggu hingga tidak sedikit yang dirugikan dari ulah mereka yang memang tidak bodoh. Aparat keamanan di negara kita yang semestinya menjadi benteng terakhir bagi keamanan kegiatan e-commerce dari tangan - tangan pembobol yang sekarang semakin tidak mempunyai kesabaran lagi ini, ternyata juga tidak mampu bekerja dengan maksimal dan banyak hal yang menjadi kendala tentang ketidakmampuan aparat mengatasi para hacker ini, bisa dari kemampuan SDM yang mungkin masih lemah dalam bidang IT, bisa juga dari perangkat yang tidak mendukung gerakan aparat mem-block kegiatan para hacker itu.

Karena itu aspek dan faktor hukum yang perlu menjadi perhatian dalam mengantisipasi cyberspace ini antara lain perlu dibentuk badan pengawas penggunaan internet di Indonesia. Tugas utama badan ini adalah menyiapkan infrastruktur hukum terkait dengan tindakan kejahatan internet di Indonesia. Disamping itu diperlukan reinterpretasi yang lebih jelas dari KUHP untuk tindak kejahatan yang tidak secara nyata berkait dengan obyek fisik. Sementara badan pengawas lain (dibentuk dari berbagai pakar pendidikan, teknologi informasi, pemerintah dan hukum), dapat berfungsi mengawasi terjadinya transaksi elektronis yang ada dalam internet, Sehingga dapat diketahui nilai uang dan devisa yang beredar. Penggunaan KUHP untuk perlindungan privasi pada cyberspace terbatas dengan analogi pasal-pasal pelanggaran pidana yang pararel dengan pelanggaran privasi pada cyberspace, padahal disisi lain efektifitas analogi tersebut tergantung pada perluasan tafsiran pasal-pasal KUHP dan seberapa jauh kemungkinan penerapan analogi tersebut pada hukum Indonesia. Kelemahan lain yang memungkinkan terjadinya pelanggaran yakni pada aspek legal homepage di internet. Sebab saat ini belum ada hukum yang mengatur secara tegas aspek legal homepage dan internet. Itu seperti menyangkut masalah kontrak online, privasi, e-commerce, pembayaran elektronis, tanggung jawab pembuat home page dan e-mail. 
Kejahatan dan kecurangan melalui hacking tersebut membuat kesulitan dalam penanganan hukum dan pajak karena melalui hacking atau cracking tersebut seseorang bisa mengubah data dan mengganti data tertentu dengan data palsu. Hal ini kembali kepada pemerintah, sebagai penyelenggara birokrasi yang tentu harus lebih memperhatikan aspek hukum bagi segala tindak kejahatan di Internet. Di mana, pemerintah akan turun tangan apabila ada market failure atau perselisihan. Selain itu, pemerintah akan terlibat langsung dalam bidang sekuriti dan digital signature. NCA (National Certificate Authority) akan diserahkan kepada swasta murni. Sebelumnya badan yang menangani NCA tersebut akan diawasi oleh pemerintah, terutama BSN (Badan Sertifikasi Nasional). Salah satu fungsi NCA adalah melakukan sertifikasi terhadap sebuah situs tertentu termasuk mengembangkan aplikasi - aplikasi sekuriti internet dan e-commerce.

Di Amerika, beberapa waktu lalu seperti yang telah dijelaskan sedang ramai tentang kontroversi pengenaan pajak terhadap bisnis di e-commerce. Dan apakah memang sepatutnya e-commerce dikenakan pajak, demikian pula jika dengan yang ada di Indonesia. Namun memang semua itu akan terpaut dengan UU yang mengaturnya, sehingga bisa terlihat tentang keabsahan sebuah e-commerce. Transaksi melalui media digital (e-commerce) di Indonesia seperti yang telah dijelaskan masih perlu pembenahan dari sisi perundangan (Cyberlaw) agar di kemudian hari tidak terjadi perselisihan dalam menjalankannya. Pajak harus menyisipkan masalah pajak untuk transaksi lewat media e-commerce. Kesulitan itu muncul ketika transaksi dilakukan baik yang berupa bentuk B-to-B atau B-to-C. Misalnya seperti yang telah dijelaskan hubungan antara pemasok dengan pabrik, bagaimana aparat pajak mengawasi telah ada transaksi atau belum antar keduanya lewat $e$-commerce tersebut. Begitu transaksi dilakukan, dan transfer dana terjadi, siapa yang dapat memantaunya? penerapan cyberlaw masih butuh waktu lama, karena dari pihak otoritas setidaknya harus membentuk wadah baru serta melatih orang - orangnya melalui pelatihan sehinnga bentuk promosi apapun yang dilakukan di internet tentunya harus dikenai pajak.

Di Amerika Serikat The US International Revenue Code (IRC) pada dasarnya memberikan dua kriteria untuk menentukan yurisdiksi Amerika Serikat dalam mengenakan pajak pendapatan orang asing, atau dengan menggunakan kriteria ketiga yang ditentukan di dalam perjanjian antar negara (treaties). Dasar pemajakan yang pertama adalah sumber pendapatan (source of income). Menurut IRC, pendapatan kotor orang asing dikenai pajak sebesar 30\% withholding tax, apabila sumber pendapatannya berada di Amerika Serikat. Kriteria kedua tidak terletak pada apakah pendapatan tersebut berasal dari Amerika Serikat, tetapi didasarkan pada apakah pendapatan tersebut berkaitan secara efektif dengan pelaksanaan perdagangan atau bisnis di Amerika Serikat. Kriteria yang ketiga, yaitu yang berdasarkan perjanjian yang dilakukan antar negara, yang didasarkan pada tempat kedudukan pihak asing yang bersangkutan. Kalau pajak yang harus dibayar oleh wajib pajak didasarkan pada asal sumber pendapatan, timbul masalah apabila pendapatan itu diperoleh dari transaksi e-commerce. Di dalam suatu transaksi pada kegiatan e-commerce hambatannya adalah sulit untuk menentukan di mana transaksi e-commerce itu berlangsung. Apabila pajak yang harus dibayar oleh wajib pajak didasarkan pada tempat kedudukan pembayar pajak, adalah sulit untuk menentukan di mana tempat kedudukan dari wajib pajak. Apabila misalnya suatu toko online atau umumnya sering disebut toko maya (virtual store) yang dimiliki oleh orang Indonesia atau Amerika Serikat, yang situsnya didaftarkan sebagai suatu dot com, maka oleh karena cyberspace adalah borderless, di manakah tempat kedudukan yang sebenarnya dari toko maya tersebut? Lebih lanjut masalah yang timbul adalah negara mana yang berhak memungut pajak yang harus dibayar oleh toko maya milik orang Indonesia tersebut? Indonesia atau Amerika Serikat? Dan bagaimana ketentuan pajak pertambahan nilai (PPN) atas barang ekspor-impor dalam transaksi melalui media internet tersebut? Kemudian bagaimana pengenaan pajak penghasilan ( $\mathrm{PPh})$ terhadap toko maya yang bergerak melalui media internet tersebut ? Mengingat hal-hal tersebut di atas, di dalam perjanjian transaksi e-commerce hendaknya secara jelas ditentukan mengenai besarnya witholding taxes yang harus dibayar, dalam mata uang apa witholding taxes itu harus dibayar, siapa yang harus membayar pajak tersebut, dan kepada negara mana pajak tersebut harus dibayar.

\section{Solusi Permasalahan}

\section{Legalitas Dokumen dan Ketentuan PPN pada E-Commerce}

Dengan semakin berkembangnya penggunaan internet dalam melakukan transaksi bisnisnya, ada beberapa pertanyaan yang timbul tentang legalitas dan keabsahan dokumen dari transaksi e-commerce sebagai bukti pendukung transaksi yang dilakukan oleh Wajib Pajak, contohnya adalah berdasarkan pesanan (order) dari pembeli melalui internet, Wajib Pajak melakukan download dan mencetak invoice dan billing tanpa dilengkapi dengan tanda tangan basah dan stempel perusahaan dari lawan transaksi karena seluruh transaksi dilakukan tanpa kertas (paperless), seperti yang telah dijelaskan dalam bab I pada bagian latar belakang bahwa dalam suatu transaksi e-commerce, dokumen yang termuat untuk dicetak adalah dokumen 
elektronik yang umumnya menggunakan kontrak melalui media e-mail. Dalam hal ini fungsionalitas modul perhitungan total nilai transaksi sistem toko maya e-commerce tersebut terdiri dari :

a. Perhitungan sub total nilai transaksi.

b. Perhitungan biaya atau fee tambahan (Low Order fee) untuk transaksi dibawah suatu batas minimum nilai transaksi (bila ada).

c. Perhitungan komponen biaya pajak.

d. Perhitungan pengurangan nilai gift voucher dan atau kupon diskon yang dicairkan (redeemed, bila ada).

e. Perhitungan biaya pengiriman.

f. Perhitungan total keseluruhan komponen biaya di atas, dengan kata lain nilai transaksi final yang harus dibayar oleh pelanggan.

Selanjutnya Wajib Pajak menggunakan bukti transaksi e-commerce yang telah dicetak tersebut sebagai dasar di dalam menyusun pembukuan perusahaan dari keseluruhan nilai transaksi, sebagaimana telah diatur dalam Pasal 28 ayat (1) UU No. 9 Tahun 1994, di mana UU mewajibkan kepada setiap wajib pajak untuk menyelenggarakan pembukuan, yang isinya dapat menggambarkan perusahaan, modal perusahaan, utang perusahaan dan seterusnya, yang dapat mendukung dalam menghitung pajak terutang, baik Pajak Penghasilan (PPh), Pajak Pertambahan Nilai (PPN), Pajak Penjualan atas Barang Mewah (PPnBM) dan lainlain jenis pajak. Namun kemudian yang menjadi pertanyaan adalah apakah dokumen transaksi e-commerce yang dilakukan dengan cara sebagaimana diuraikan di atas dapat digunakan sebagai bukti legal yang diakui oleh fiskus?

Seperti yang kita ketahui bahwa pembukuan adalah suatu proses pencatatan yang dilakukan secara teratur untuk mengumpulkan data dan informasi keuangan dan dari pembukuan tersebut dapat dihitung besarnya pajak yang terutang. Kemudian dalam Undang-undang Nomor 8 Tahun 1997 tentang dokumen perusahaan, antara lain mengatur bahwa dokumen perusahaan adalah data, catatan, dan atau keterangan yang dibuat dan atau diterima oleh perusahaan dalam rangka pelaksanaan kegiatannya, baik tertulis di atas kertas atau sarana lain maupun terekam dalam bentuk corak apapun yang dapat dilihat, dibaca, atau didengar sedangkan Dokumen keuangan terdiri dari catatan, bukti pembukuan, dan data pendukung administrasi keuangan, yang merupakan bukti adanya hak dan kewajiban serta kegiatan usaha suatu perusahaan.

Berdasarkan ketentuan tersebut di atas bahwa pada prinsipnya penggunaan internet dalam transaksi bisnis dapat diterima dalam ketentuan perpajakan khususnya dalam ketentuan pajak pertambahan nilai (PPN). Invoice dan billing atas penjualan barang melalui internet (dokumen e-commerce) yang di-download dan dicetak sendiri oleh perusahaan dapat dijadikan dasar untuk menyusun pembukuan perusahaan dan diakui secara fiskal sepanjang secara material dapat dibuktikan arus kas dan arus barangnya serta didukung dengan bukti pendukung dari pihak eksternal seperti bukti penerimaan barang dan dokumen PEB bila penjualan dimaksud merupakan penjualan ekspor.

Dengan adanya bukti tersebut maka yang bersangkutan tetap dapat dikenai pajak pertambahan nilai (PPN) walaupun transaksi berjalan secara online tanpa adanya bukti secara fisik karena selain adanya dokumen elektronik yang menjadi bukti transaksi, juga pada transaksi tersebut telah terdapat unsur-unsur yang memenuhi untuk dapat dikenakan pajak pertambahan nilai (PPN) yaitu, adanya penyerahan barang baik yang berwujud atau tidak, di mana yang diserahkan adalah Barang Kena Pajak (BKP) yang menurut pasal 1 angka 3 UU PPN adalah barang berwujud yang menurut sifat atau hukumnya dapat berupa barang bergerak atau barang tidak bergerak dan barang tidak berwujud yang dikenakan pajak berdasarkan UU PPN kecuali barang - barang yang tidak dikenakan pajak pertambahan nilai (PPN), misalnya adalah barang hasil pertanian, barang hasil perkebunan, barang hasil kehutanan, barang hasil peternakan, barang hasil perburuan, barang hasil penangkaran, barang hasil perikanan, barang hasil budidaya, barang hasil pertambangan dan barang-barang kebutuhan pokok sehari-hari. Kemudian yang menyerahkan adalah Pengusaha Kena Pajak (PKP) yaitu menurut pasal 1 angka 15 UU PPN adalah pengusaha yang melakukan penyerahan BKP atau jasa kena pajak (JKP) yang dikenakan pajak berdasarkan UU PPN serta melakukan pemanfaatan barang tidak berwujud dari luar Daerah Pabean ke dalam, di mana penyerahannya harus di Daerah Pabean, yaitu daerah Republik Indonesia dan PKP yang menyerahkan harus dalam lingkungan perusahaan atau pekerjaannya terhadap barang yang dihasilkan.

Setiap melakukan pemungutan PPN atau PPN dan PPnBM wajib membuat Faktur Pajak, yang disebut Faktur Pajak Keluaran sebagai bukti pemungutan. Khusus atas penyerahan BKP atau JKP langsung kepada konsumen akhir atau konsumen yang tidak dapat diidentifikasi dibuat Faktur Pajak Sederhana, walaupun tidak dapat digunakan sebagai Faktur Pajak Masukan. 
Untuk menghitung besarnya pajak pertambahan nilai (PPN) terutang, harus dipahami terlebih dahulu tentang dasar perhitungan PPN (DPP), saat terutangnya PPN dan tarif PPN. Dalam hal ini dasar perhitungan PPN adalah sebagai berikut:

- Untuk PPN Barang adalah harga jual,

- Untuk PPN Jasa adalah penggantian,

- Untuk PPN Impor adalah Nilai Impor,

- Untuk PPN atas pemanfaatan Barang Kena Pajak Tidak Berwujud atau Jasa Kena Pajak dari luar negeri adalah jumlah yang dibayarkan kepada pihak yang menyerahkan BKPTB atau JKP,

- Untuk PPN atas pemakaian sendiri, pemberian cuma-cuma, penyerahan media rekaman suara/gambar, penyerahan film, persediaan BKP tersisa (likuidasi), aktiva yang tujuan semula tidak untuk dijual dan Jasa Pengiriman Paket, adalah Nilai Lain,

- Untuk PPN Ekspor adalah Nilai Ekspor.

Dalam hal ini tarif PPN tentunya menerapkan tarif yang proporsional dan tunggal, sebagai sarana dalam rangka memudahkan melakukan kredit pajak dalam kegiatan usaha e-commerce.

\section{Ketentuan UU PPh pada E-Commerce}

Seperti yang telah dijelaskan pada bab I bagian latar belakang bahwa Kegiatan usaha e-commerce dilakukan melalui apa yang disebut Application Service Provider (ASP), di mana ASP menyediakan disk space untuk disewa pengusaha untuk menawarkan produksinya kemudian perusahaan yang menyewanya mengisinya dengan perangkat lunak yang dapat diakses oleh para calon pembeli dan kemudian perusahaan tersebut menawarkan barang produksinya. Perlakuan pajak penghasilan terhadap transaksi bisnis tersebut akan dibahas dengan mengambil asumsi pertama bahwa ASP dimaksud berada di Indonesia dan server yang disebutkan diatas tidak mempunyai back-up servers sehingga server tersebut merupakan satu-satunya server yang menjadi objek analisis.

Server dimiliki oleh wajib pajak Indonesia. Bagi wajib pajak dalam negeri yang mempunyai server yang berlokasi di dalam negeri dan menyewakannya kepada wajib pajak lainnya, penghasilan yang diperolehnya dari kegiatan tersebut adalah penghasilan atas sewa dari space yang bersangkutan. Dari sudut pandang penyewa, apakah penyewa tersebut wajib memotong sewa yang dibayarkannya. Pemotongan PPh dalam Undang-undang Pajak Penghasilan yang menyangkut pembayaran kepada wajib pajak dalam negeri, diatur di beberapa pasal yaitu pasal 4 ayat (2), pasal 22, dan pasal 23.

Ketentuan yang paling dekat dengan kasus di atas adalah pasal 23, karena cakupan dari pasal tersebut meliputi dividen; bunga; royalty; hadiah atau penghargaan; sewa dan penghasilan lain sehubungan dengan penggunaan harta; imbalan sehubungan dengan jasa teknik, jasa manajemen, jasa konstruksi, jasa konsultan. Apabila disimak cakupan PPh Pasal 23 tersebut maka yang paling mendekati adalah sewa sehubungan dengan penggunan harta. Ketentuan Pasal 23 yang menyangkut penghasilan dari penggunaan harta tidak terlalu jelas ruang lingkupnya. Apabila pengertian "harta" diberi interpretasi yang luas maka mencakup harta berwujud dan harta tak berwujud. Yang pasti adalah bahwa suatu website bukan merupakan harta berwujud, sehingga apabila pengertian "harta" diberi arti yang luas maka penyewaan "website" akan dicakup dalam ketentuan Pasal 23 dimaksud. Pasal 23 mensyaratkan bahwa dalam hal yang membayar adalah orang pribadi maka orang tersebut harus ditunjuk sebagai pemotong.

Dengan demikian apabila penyewa website adalah orang pribadi pembayaran yang dilakukan kepada pemilik ISP tidak perlu memotong sepanjang yang bersangkutan tidak ditunjuk sebagai pemotong. Sebagaimana yang telah dijelaskan agar supaya website menjadi aktif dan dapat dipergunakan diperlukan perangkat lunak yang sepsifikasinya atau jenisnya tergantung kepada pemiliknya sesuai dengan kebutuhannya. Perangkat lunak ini diperlukan baik oleh pemilik ISP maupun penyewanya. Untuk keperluan tersebut baik pemilik ISP maupun penyewa website akan meminta seorang programmer untuk membuat program (perangkat lunak) sesuai dengan kebutuhannya. Transaksi tersebut akan menimbulkan implikasi pajak terutama masalah pemotongan PPh. Dengan perkataan lain, apakah pembayaran atas perangkat lunak tersebut merupakan objek pemotongan. Hal ini ditentukan masuk jenis penghasilan apa pembayaran dimaksud. Hanya ada dua jenis penghasilan yang paling mendekati yaitu royalti atau jasa. Pada dasarnya "royalti" adalah imbalan sebagai pengganti penggunaan atas hak, sehingga kepemilikan hak tersebut tetap pada penemunya/pemilik.

Bila dibandingkan dengan kasus perangkat lunak dalam kaitannya dengan website, perangkat lunaknya sudah berpindah tangan kepada yang membelinya. Atas dasar pertimbangan ini maka pembayaran atas 
perangkat lunak tersebut masuk dalam kategori "jasa", yang berdasarkan ketentuan Pasal 23 masuk dalam kelompok jasa teknik, yang dasar pemotongannya adalah penghasilan neto. Kemudian bagaimana dengan perusahaan yang berdomisili di luar negeri? Apakah ketentuan pajaknya akan berbeda dengan yang ada di dalam negeri?

Implikasi pajak yang agak rumit dari kegiatan usaha dengan e-commerce juga timbul dalam hal penyewa atas space di ISP (penyedia jasa Internet) adalah perusahaan yang berdomisili di luar negeri. Pertama-tama adalah apakah dengan hadirnya perusahaan luar negeri melalui suatu situs web, perusahaan tersebut dapat dianggap mempunyai bentuk usaha tetap (BUT) di Indonesia? Definisi bentuk usaha tetap (BUT) diatur di Pasal 2 ayat (5) Undang-undang PPh, yang berdasarkan rinciannya memberikan indikasi bahwa keberadaan di Indonesia melalui harta berwujud, disamping kegiatan pemberian jasa di Indonesia. Dengan demikian, apabila sebuah perusahaan luar negeri melakukan kegiatan usaha melalui website, sesuai dengan definisi, kegiatan ini tidak menimbulkan bentuk usaha tetap (BUT).

Hal yang sama juga dapat dikatakan bila perusahaan luar negeri tersebut adalah perusahaan yang berdomisili di negara yang mempunyai P3B dengan Indonesia. Namun, bila kegiatan dari perusahaan tersebut memberikan jasa melalui website-nya maka pembayaran yang diterima dari Indonesia merupakan objek pemotongan PPh Pasal 26, dengan asumsi bahwa perusahaan tersebut berdomisili di negara-negara yang tidak mempunyai P3B dengan Indonesia. Server dimiliki oleh wajib pajak luar negeri. Dalam hal ISP dimiliki oleh perusahaan di luar negeri, masalah utama yang perlu diangkat adalah apakah kehadiran perusahaan tersebut melalui server dapat dikatakan bahwa perusahaan tersebut mempunyai bentuk usaha tetap (BUT) di Indonesia? Sekali lagi dapat dikatakan bahwa Undang-undang Pajak Penghasilan belum mencakup masalah ini, sehingga apabila definisi bentuk usaha tetap (BUT) mencakup ISP maka Pasal 2 ayat (5) perlu diubah dan ditambah.

Hal ini terkait rencana pemerintah tentang menjaring pajak penghasilan $(\mathrm{PPh})$ warga negara asing yang berbisnis musiman di Indonesia. Pembahasan Rancangan Undang-Undang Pajak Penghasilan ( $\mathrm{PPh})$ mulai masuk masalah teknis. Panitia Kerja mengemukakan RUU PPh baru menyelesaikan pembahasan 110 daftar inventaris masalah (DIM) dari 600 DIM. Ketua Panitia Khusus RUU PPh, Melchias Markus Mekeng mengungkapkan tentang pembahasan bentuk usaha tetap (BUT) terkait maraknya perusahaan-perusahaan milik warga negara asing yang beroperasi di Indonesia. Pemerintah ingin mengenakan pajak penghasilan terhadap mereka dengan menjaringnya sebagai bentuk usaha tetap (BUT). Berkaitan dengan niat itu, penetapan status bentuk usaha tetap (BUT) dapat bersifat terbuka (open list) tetapi harus ada definisi yang lebih spesifik sehingga bisa tercipta kriteria bentuk usaha tetap (BUT) yang bersifat khusus pula. Dalam hal ini pemerintah mengusulkan 15 jenis bentuk usaha tetap (BUT) yang masuk dalam dan menjadi subjek PPh. Mereka adalah orang pribadi, warisan yang belum dibagikan, badan hukum, dan badan usaha. Termasuk di dalamnya berupa kantor perwakilan perusahaan asing, gudang, showroom, tempat penjualan, serta agen dan kriteria ini untuk mencakup orang yang tidak tinggal di Indonesia atau tidak menetap di Indonesia lebih dari 183 hari atau setahun. Hal ini terkait dengan permasalahan di dalam mengantisipasi aturan untuk menjaring transaksi e-commerce, terutama untuk pajak penghasilan bagi penyedia jaringan atau jasa transaksinya.

Jika situasi tersebut dikaitkan dengan P3B maka ada dua hal yang perlu dipertimbangkan, yaitu pertama, dalam UU domestik dari negara-negara yang terlibat mempunyai aturan tersebut, dan kedua, sesuai dengan commentary dari OECD, keberadaan ISP memenuhi ketentuan Pasal 5 dari OECD Model. Pasal 5 dari OECD Model mensyaratkan bahwa peralatan apapun yang digunakan sebagai server, sifatnya harus tetap. Artinya server tersebut harus mempunyai lokasi yang tetap dan pasti. Secara garis besar, semua transaksi dalam kaitannya dengan persiapan untuk mengoperasikan website, dalam hal server dimiliki oleh wajib pajak luar negeri.

Misalkan salah satu dari penyewa website, yaitu wajib pajak luar negeri, menggunakan website-nya untuk menyimpan informasi yang menyangkut industri tertentu, yang kemudian ditawarkan kepada pihak ketiga untuk menjadi pelanggannya (subscriber). Pelanggan tersebut membayar iuran untuk dapat mengakses informasi dimaksud. Impikasi pajak penghasilan dari transaksi tersebut adalah perlakuan pajaknya terhadap pembayaran yang di lakukan oleh pelanggan. Yang prtama-tama dilakukan adalah menentukan masuk dalam kategori penghasilan apa pembayaran tersebut. Dari sudut pandang UU Pajak Penghasilan, pembayaran untuk informasi yang belum diungkapkan ke publik atau yang tidak dapat diperoleh melalui sarana yang tersedia di publik, masuk dalam kategori "royalti", sebagaimana ditegaskan dalam penjelasan Pasal 4 ayat (1) huruf h.

Jadi kalau pelanggannya adalah wajib pajak Indonesia maka yang bersangkutan harus memotong PPh Pasal 26, dengan catatan bahwa tarifnya tergantung domisili dari wajib pajak yang menerimanya. 
Pemotongan $\mathrm{PPh}$ pasal 26 ini bisa tidak final jika server tersebut dianggap sebagai bentuk usaha tetap (BUT). Seandainya demikian maka pembayaran untuk informasi tersebut diperlakukan sebagai penghasilan usaha (business income) dari wajib pajak yang menerimanya. Sebaliknya apabila berdasarkan Undangundang Pajak Penghasilan "server" tersebut tidak/belum masuk dalam definisi bentuk usaha tetap (BUT) maka pemotongan PPh Pasal 26 menjadi final. Server berada di luar negeri. Implikasi pajak penghasilan terhadap penghasilan yang bersumber dari Indonesia sebagai akibat dari kegiatan usaha melalui e-commerce yang server-nya berada di luar negeri, mirip dengan apabila server yang berada di Indonesia dimiliki oleh wajib pajak luar negeri.

Dalam hal demikian maka ketentuan dari Undang-undang Pajak Penghasilan yang dapat diterapkan adalah Pasal 26, dengan catatan bahwa pembayaran tersebut diterima oleh wajib pajak dari Negara yang tidak mempunyai P3B dengan Indonesia.

Di mana setiap pembayaran yang bersumber dari Indonesia yang membayar, termasuk orang pribadi, harus memotong PPh Pasal 26 sebesar 20\%. Apa yang diuraikan di atas menunjukkan bahwa dalam hal ecommerce melibatkan wajib pajak luar negeri, faktor utama yang memungkinkan Indonesia dapat mengenakan pajak adalah apakah suatu web page dapat menimbulkan bentuk usaha tetap (BUT).

Sebagaimana yang telah dijelaskan di atas, web page ini dimasukkan dalam host komputer. Teorinya web page tersebut akan menjadi bentuk usaha tetap (BUT) di negara dimana host komputer-nya berada, dengan catatan (sesuai dengan OECD Model) bahwa computer tersebut tetap berada di satu tempat. Jadi hal ini perlu menjadi pertimbangan dalam rangka upaya ekstensifikasi. Namun demikian, perlu disadari bahwa bagi pemilik server atau web page sangat mudah memindahkannya ke tempat lain atau Negara lain sehingga tidak terperangkap ke dalam definisi bentuk usaha tetap (BUT).

Pemenuhan kewajiban perpajakan. Di samping pendekatan yuridis fiskal, pendekatan dari segi administratif juga perlu dipikirkan. Transaksi melalui e-commerce sulit dilacak tanpa tersedianya data atau informasi yang diperlukan, terutama apabila transaksi tersebut dilakukan melalui server yang berada di luar negeri. Pemenuhan kewajiban perpajakan, terutama yang menyangkut kewajiban memotong PPh Pasal 26. $\mathrm{Hal}$ ini akan sangat tergantung kepada terbentuknya badan pengawas yang bertugas untuk mengawasi lalu lintas komunikasi melalui internet agar tidak menimbulkan terjadinya kejahatan di dunia maya (cybercrime).

\section{Sarana - Sarana Pendukung}

Memasuki Era Modernisasi dalam Sistem Administrasi Perpajakan, pada setiap Kantor Pelayanan Pajak (KPP) saat ini menuju arah yang lebih baik dan transparansi. Penerapan dari sisi pengisian pajak maupun pelaporan pajak sudah diterapkan dengan menggunakan media elektronik yang sekarang ini kita kenal dengan e-SPT (untuk pengisian pajak), e-Filling (sistem pelaporan pajak melalui media internet secara online dan real time), e-regristation (Sistem Pendaftaran Wajib Pajak secara online. Sistem ini terbagi dua bagian, yaitu sistem yang dipergunakan oleh Wajib Pajak yang berfungsi sebagai sarana pendaftaran Wajib Pajak secara online dan sistem yang dipergunakan oleh Petugas Pajak yang berfungsi untuk memproses pendaftaran Wajib Pajak) dan MP3 (Monitoring Pelaporan Pembayaran Pajak. Sistem ini adalah sistem yang dibuat oleh Direktorat Jenderal Pajak untuk memonitor seluruh pembayaran pajak yang dilakukan pada bank dan kantor pos secara online).

Terkait dengan hal tersebut penerapan pengisian laporan pajak melalui aplikasi e-SPT PPN 1107 sejak masa pajak Januari 2007 sudah diberlakukan secara Nasional (Per 146/PJ/2006). Penerapan e-SPT PPh Masa yaitu, PPh Masa Pasal 21, 22, 23, 4 ayat 2 dan 15 dalam hal ini tidak menutup kemungkinan akan juga diberlakukan secara Nasional seiring dengan modernisasi di lingkungan Dirjen Pajak dan Kantor Pelayanan Pajak (KPP). Pemerintah dalam hal ini juga menargetkan pembentukan kantor pajak pratama (KPP) dan kantor pelayanan, penyuluhan dan konsultasi perpajakan (KP2KP) modern di seluruh Indonesia yang akan selesai pada tahun 2008. Hal tersebut bertujuan untuk menyikapi perkembangan dunia usaha melalui media internet khususnya kegiatan usaha e-commerce yang semakin cepat ini, agar Wajib Pajak dapat melalukan pembayaran pajak secara lebih mudah, aman dan transparan serta meningkatkan kepatuhan Wajib Pajak terhadap kewajiban administrasi perpajakannya.

Selain itu Dirjen Pajak juga menerapkan beberapa aplikasi baru yaitu, situs internet Dirjen Pajak (http://www.pajak.go.id) yang memuat peraturan perpajakan dan informasi perpajakan, pengembangan pengetahuan dasar (knowledge base) dibeberapa Kanwil yang berisi petunjuk praktis tentang beberapa permasalahan di bidang perpajakan yang dapat dijadikan pedoman oleh Fiscus dalam menjawab pertanyaan dari wajib pajak, situs intranet Dirjen pajak yang merupakan sarana komunikasi internal Dirjen pajak dan 
sekaligus pintu masuk menuju program aplikasi PK-PM dan MP3, program aplikasi PK-PM yang berfungsi untuk menyandingkan faktur pajak masukan PKP pembeli dengan faktur pajak keluaran PKP penjual, program aplikasi Monitoring Pelaporan dan Pembayaran Pajak (MP3) yang berfungsi untuk memonitor dan mengawasi penerimaan pajak secara online.

Selain dari penerapan beberapa aplikasi baru, peningkatan standard dan kualitas juga harus didukung oleh sumber daya manusia (SDM) pada pegawai Dirjen Pajak itu sendiri. Selama ini struktur organisasi Dirjen pajak didasarkan pada jenis pajak. Dengan struktur organisasi seperti ini pelaksanaan tugas di lapangan seringkali menimbulkan ketidakefisienan yang mengakibatkan pelayanan dan pengawasan tidak optimal. Dalam kurun waktu Selama 4 tahun terakhir ini, Dirjen pajak telah melakukan beberapa reformasi perpajakan dan modernisasi administrasi perpajakan yang mengacu pada cetak biru. Disamping pembentukan kantor dan penerapan sistem modern, modernisasi lebih lanjut ditandai dengan penerapan teknologi informasi terkini dalam pelayanan perpajakan (e-SPT).

Harus diakui profesionalisme pegawai Dirjen pajak masih perlu banyak ditingkatkan. Hasil survei dari pihak ketiga yang antara lain dilakukan oleh Hay Group Consultant terhadap pendapat wajib pajak menunjukkan Dirjen pajak mempunyai kelemahan pada sumber daya manusia (SDM), sosialisasi ketentuan dan distorsi pada pemeriksaan pajak. Kelemahan ini diperkuat dengan banyaknya surat-surat masuk yang memerlukan penugasan lebih lanjut. Salah satu yang menjadi penyebab kelemahan sumber daya manusia (SDM) adalah target penerimaan yang merupakan satu pressure tersendiri sehingga mendorong tenagatenaga terampil diarahkan ke hal-hal yang bersifat teknis. Akibatnya fungsi lain yang tidak kalah penting seperti penyuluhan, pemrosesan data, perencanaan pegawai dan penyusunan konsep aturan mengalami banyak kekurangan baik dari sisi jumlah maupun kapasitas sumber daya manusia (SDM) nya.

Dengan melihat hal tersebut, maka tujuan utama dibangunnya e-SPT adalah untuk menerapkan sistem administrasi perpajakan modern pada KPP di lingkungan Kanwil Direktorat Jendral Pajak Wajib Pajak Besar dapat diukur dan dipantau, mengingat sistem tradisional sangat sulit untuk dilakukan. Kedua untuk menerapkan sistem administrasi perpajakan modern yang meliputi modernisasi struktur organisasi, modernisasi prosedur organisasi, modernisasi strategi organisasi, dan modernisasi budaya organisasi KPP di lingkungan Kanwil Dirjen Pajak Wajib Pajak Besar terhadap kepatuhan wajib pajak pada KPP di lingkungan Kanwil Dirjen Wajib Pajak Besar dapat ditelaah dan dikaji untuk pencapaian tujuan utama. Ketiga adalah Sebagai informasi dan bahan evaluasi atas penerapan sistem administrasi perpajakan modern di lingkungan Kanwil Dirjen Pajak Wajib Pajak Besar sebagai prototipe Kanwil dan KPP percontohan sehingga dapat mendorong digulirkannya reformasi administrasi perpajakan jangka menengah oleh Dirjen Pajak yang menjadi prioritas dalam reformasi perpajakan terutama dalam melanjutkan penerapan sistem administrasi perpajakan modern pada kantor-kantor pajak lainnya diseluruh Indonesia dan sebagai informasi yang perlu diperhatikan bagi Dirjen Pajak dalam memahami aspek - aspek yang berpengaruh terhadap kepatuhan wajib pajak sebagai salah satu tujuan dari modernisasi administrasi perpajakan melalui penerapan sistem administrasi perpajakan modern. Keempat adalah sebagai informasi yang bermanfaat bagi masyarakat perpajakan di Indonesia dan sebagai informasi yang bermanfaat bagi masyarakat umum secara luas serta secara khusus bermanfaat dalam mendorong kepercayaan masyarakat terhadap administrasi perpajakan di Indonesia. Yang kelima adalah meningkatkan kemampuan administrasi perpajakan di dalam menghadapi kegiatan usaha yang semakin global khususnya di bidang e-commerce.

Reformasi administrasi perpajakan secara keseluruhan berpengaruh terhadap akuntabilitas orang Dirjen Pajak. Tujuan administrasi perpajakan adalah mendorong kepatuhan wajib pajak reformasi administrasi. Akuntabilitas organisasi sebagai bagian dari reformasi administrasi perpajakan memberikan pengaruh yang cukup besar terhadap kepatuhan wajib pajak. Reformasi administrasi perpajakan bersamasama dengan akuntabilitas organisasi mempunyai pengaruh sangat besar terhadap kepatuhan wajib pajak terutama dalam menghadapi abad elektronik dewasa ini. Keefisienan sarana - sarana pendukung tersebut sangat menentukan keberhasilan Dirjen Pajak dalam meningkatkan kualitas perpajakan khususnya pada kegiatan usaha melalui e-commerce

\section{Pajak E-Commerce Memang Jadi Persoalan Dunia}

Menteri Keuangan Sri Mulyani Indrawati mengatakan masalah pajak dari perdagangan secara elektronik saat ini sedang menjadi persoalan dunia dan sedang diupayakan solusi yang tepat untuk mengatasi permasalahan tersebut. Menurutnya, dengan adanya berbagai macam ide mengenai 'e-commerce' yang menggunakan platform 'online', dan penjual pembeli dihubungkan secara elektronik, ini menimbulkan sesuatu persoalan yang sangat serius. 
Menkeu mengatakan pihaknya sedang mencari solusi yang memadai untuk mengatasi fenomena global atas transaksi perdagangan secara elektronik tersebut agar para pelaku usahanya bisa dikenakan pajak yang sesuai dengan aktivitas ekonominya. Saat ini Kementerian Keuangan sedang membuat kajian maupun proposal mengenai bentuk pemungutan pajak bagi pelaku usaha perdagangan secara daring, sebelum nantinya terbit peraturan pungutan pajak secara tertulis terkait hal tersebut. Peraturan tersebut harus dibandingkan dengan negara lain agar tidak membuat rezim peraturan yang tidak kompetitif, sehingga tidak mampu mengoleksi penerimaan negara.

\section{Mengapa Pajak E-Commerce Sulit Diterapkan?}

Bisnis e-commerce memiliki karakter tersendiri. Dengan jaringan internet sebagai tulang punggungnya, maka proses transaksi bisa dilakukan dengan cepat dan praktis. Karakteristik yang berbeda dengan perdagangan konvensional tersebut ternyata mendatangkan masalah tersendiri, yakni sulitnya menetapkan peraturan pajak yang jelas dan adil. Setidaknya ada dua hal yang menjadi masalah perpajakan disebabkan oleh transaksi e-commerce, yakni pajak langsung dan pajak tidak langsung.

Pajak tidak langsung atau indirect tax merupakan pajak yang dikenakan terhadap barang konsumsi seperti halnya pada pajak pertambahan nilai (PPN). Kesulitan menetukan pajak tidak langsung ini disebabkan oleh perkembangan dunia teknologi informasi, sehingga telah menambah jenis barang baru berupa produk digital atau perangkat lunak (software) yang dapat diperjualbelikan secara online. Hal ini tentu berbeda dengan perdagangan konvensional yang barang atau produknya dapat dilihat secara fisik. Transaksi jual beli produk digital dilakukan secara online yang hanya melibatkan dua belah pihak, tanpa diketahui sama sekali oleh negara atau kedua negara dari pihak pembeli dan penjual.

\section{E-commerce pajak}

Beragam produk saat ini telah dapat diubah ke dalam bentuk digital, seperti buku, video, lagu, film, dan sejenisnya. Barang-barang tersebut dapat diperjualbelikan secara online melalui internet. Hal ini menjadi satu kendala yang dialami pihak perpajakan untuk mengetahui transaksi tersebut. Oleh karena itu, mengikuti perkembangan era digital yang semakin cepat dan kompleks, maka perlu adanya sebuah aturan dan kebijakan perpajakan yang menjadi dasar serta mengantisipasi potensi masalah perpajakan yang mungkin terjadi di masa mendatang.

Jika ditinjau dari sudut pandang pajak tidak langsung (indirect tax), ternyata ada dua masalah utama yang muncul terkait dengan e-commerce ini.

Yang pertama disebabkan oleh sifat transaksi e-commerce yang tanpa batas, sehingga mampu menembus batas-batas negara. Jika kita mengamati proses transaksi jual beli barang yang tak berwujud melalui jaringan online, maka produk tersebut bisa terbebas dari pengenaan atau pungutan pajak tidak langsung. Misalnya, seseorang membeli sebuah buku berbentuk digital yang dibeli dari toko online di luar negeri. Nah, ketika barang tersebut telah sampai di perangkat komputer si pembeli yang berlokasi di sebuah kota di Indonesia, maka barang tersebut akan luput atau terbebas dari pengenaan pajak penjualan ataupun peraturan pajak impor yang berlaku di Indonesia. Hal ini tentu berbeda perlakuannya manakala buku tersebut berbentuk cetak biasa (nondigital). Di saat produk buku tersebut masuk ke wilayah Indonesia, maka akan dikenakan tarif pajak sesuai dengan peraturan yang berlaku negara ini. Inilah yang menjadi satu topik permasalahan pajak e-commerce di Indonesia dan hampir semua negara di dunia.

Permasalahan kedua yang menjadi kendala dalam penerapan pajak e-commerce adalah upaya bagaimana caranya mendeteksi transaksi barang berbentuk digital agar bisa dikenakan penerapan kepatuhan perpajakannya, terutama proses transaksi barang digital yang terjadi lintas negara. Besar kemungkinan adanya potensi pajak yang hilang tatkala transaksi tersebut tidak dapat diketahui oleh otoritas pajak di kedua negara asal penjual dan pembeli.

Untuk pajak penghasilan dalam pajak yang bersifat langsung atau direct tax, ternyata ditemukan beberapa kendala dan masalah yang disebabkan oleh karakter bisnis e-commerce tersebut. Problem pertama adalah terjadinya kebimbangan dalam menentukan bentuk usaha tetap atau permanent establishment (BUT). Biasanya dalam melakukan usaha perdagangan secara konvensional, sebuah perusahaan luar negeri yang ingin membuka cabang di Indonesia, maka akan dikenakan pajak atas segala kegiatan usahanya. Namun, dengan karakter dan sifat usaha e-commerce, kebutuhan untuk membuka cabang menjadi tidak lagi diperlukan. Sementara pelaku usaha luar negeri tersebut bebas memasarkan produknya di berbagai negara termasuk Indonesia. 
Permasalahan pajak kedua yang muncul dalam e-commerce adalah sulitnya menentukan negara mana yang berhak untuk menetapkan dan memungut pajak atas penghasilan yang diperoleh dari transaksi $e$ commerce. Mengapa ini terjadi? Karena sangat sulit untuk melacak identitas perusahaan ataupun individu yang memainkan peran utama dalam bisnis. Apalagi perdagangan yang berbentuk produk digital elektronik.

\section{Masalah/Hambatan dalam E-Commerce}

Dari uraian di atas, dapat diidentifikasi masalah-masalah/hambatan dalam pengelolaan E-Commerce adalah sebagai berikut :

Pengimplementasian ecommerce di Indonesia masih harus menempuh jalan yang panjang dan berliku. Berbagai hambatan yang ada dalam pengimplementasiannya dapat berupa teknis dan non-teknis yang kesemua itu membutuhkan kerjasama yang utuh antara pemerintah, pengembang dari e-commerce, pebisnis dan para konsumen pemanfaatnya. Seperti produk-produk teknologi informasi lainnya seperti juga $e$ government, e-commerce masih membutuhkan waktu yang lama untuk dapat dikenal dan diterima di Indonesia. Berbagai hambatan tersebut dapat diklasifikasikan sebagai berikut:

\section{Dukungan pemerintah.}

Dukungan pemerintah yang masih belum jelas ditambah dengan belum adanya kebijakankebijakan yang mendukung perkembangan dari e-commerce ini dikeluarkan, belum jelasnya deregulasi dari system teknologi informasi khususnya internet yang merupakan salah satu tulang punggung dari perkembangan e-commerce, perbaikan sistem pabeanan dan deregulasi dalam ekspor impor barang.

2. Perkembangan infrastruktur yang lambat.

Salah satu hambatan utama adalah masih kurangnya insfrastrukur yang ada dan belum merata kepelosok Indonesia. Dibutuhkan keseriusan pemerintah untuk secara bertahap membangun infrastrukur yang baik dan terprogram sehingga secara bertahap, rakyat Indonesia mulai dapat dikenalkan dengan internet sebagai salah satu hasil dari perkembangan teknologi informasi dengan biaya yang murah dan terjangkau.

3. Kurangnya sumber daya manusia.

Kurangnya SDM Indonesia yang benar-benar menguasai sistem e-commerce ini secara menyeluruh, yang tidak saja menguasai secara teknis juga non-teknis seperti sistem perbankan, lalu lintas perdagangan hingga sistem hukum yang berlaku. Salah satu alasan yang cukup utama yaitu masih kurangnya ketersediaan informasi, mulai dari buku-buku referensi, jurnal, majalah/tabloid yang membahas tentang e-commerce juga sarana pendidikan, seminar, workshop hingga pusat-pusat pengembangan yang dibangun antara pemerintah, pusat-pusat pendidikan dan tenaga ahli di bidang $e$ commerce.

4. Dukungan dari institusi finansial seperti bank dan asuransi.

Belum banyaknya bank yang telah membangun system 'electronic banking' nya dengan baik, selain itu perbankan Indonesia juga masih sulit untuk melakukan transaksi dengan menggunakan mata uang lain, apalagi dalam jumlah nilai yang kecil serta belum adanya pihak ketiga sebagai penjamin transaksi secara online yang benar-benar berada di Indonesia.

5. Perbaikan sistem perdagangan yang ada.

Adanya keseriusan dari pemerintah untuk menderegulasi system perdagangan yang memberi kesempatan luas bagi berkembangnya UKM, sistem jaringan pengiriman yang baik dan aman, tidak adanya gangguan diperjalanan dan di institusi yang berhubungan dengannya seperti pelabuhan, pintu-pintu perbatasan dan international airport. Serta yang paling penting deregulasi di bidang ke pabeanan dan pajak yang mendukung sistem $e$-commerce ini berkembang. Kesemuanya itu bukanlah penghalang yang menjadi hambatan bagi perkembangan e-commerce di Indonesia, diharapkan sekali hambatan tersebut menjadi poin penting untuk mulai mengembangkan e-commerce di Indonesia. Sedangkan jika kita melihat peluang-peluang yang ada, kesemuanya itu tentunya diharapkan memberikan energi atau semangat khusus bagi semua pihak bahwa sebenarnya ecommerce dapat menjadi solusi baru bagi ketertinggalan kita disemua bidang selama ini, seperti:

a. Jumlah penduduk Indonesia yang besar merupakan pangsa pasar yang masih dapat banyak digarap

b. Kondisi geografis yang sangat mendukung berkembangnya e-commerce, dengan begitu banyaknya pulau-pulau yang tersebar diseluruh nusantara, e-commerce merupakan salah satu jalan terbaik untuk meningkatkan bisnis antar pulau

c. Begitu banyaknya bahan alam yang dapat diolah menjadi produk-produk yang bagus dan istimewa 
d. Begitu banyaknya adat-istiadat dan budaya yang ada, merupakan sumber inspirasi bagi perkembangan usaha kerajinan yang dapat menjadi sumber perdagangan dan komoditi pariwisata jika dikelola dengan baik

Sementara itu dalam pertemuan Asosiasi E-commerce Indonesia (idea), Menteri Kominfo Rudiantara mengatakan bahwa pemerintah akan mengatur peraturan terkait e-commerce mulai dari layanan logistik, sistem pembayaran, dan pajak. Diharapkan pembahasan peraturan ini bisa rampung selambatnya di penghujung tahun. (The Jakarta Post; 7 April 2017)

Pertemuan tersebut dihadiri oleh sejumlah anggotanya seperti Tokopedia dan Zalora, serta juga pelaku industri yang masih berhubungan seperti e-payment dan logistik.

Dalam pertemuan tersebut, Ketua idEA Daniel Tumiwa mengatakan bahwa E-commerce kini sudah mencapai titik pertumbuhan tertinggi setelah tumbuh secara organic, kini saatnya untuk menata kembali beberapa peraturan yang mendasar. Beberapa masalah krusial yang muncul adalah seperti infrastruktur yang masih buruk, kesulitan mengatur e-payment, dan keamanan bertransaksi.

Berikut adalah enam masalah krusial selengkapnya yang diharapkan bisa menemui jalan keluar terkait industri e-commerce lokal:

\section{Infrastruktur dan prosedur lebih mendalam}

Tantangan infrastruktur di Indonesia tidak bisa diselesaikan oleh perusahannya sendiri. Industri ecommerce berharap pemerintah juga turut mengambil langkah. Utamanya terkait infrastruktur internet yang belum stabil dan transportasi yang kerap sulit diandalkan. Prosedur perizinan dari bea cukai untuk pengantaran ke negara lain tidak efisien.

\section{Industri e-commerce menginginkan pembayaran non-tunai}

Masyarakat masih mengandalkan pembayaran tunai dan edukasi tentang sistem pembayaran alternatif. Ketergantungan terhadap pembayaran secara tunai harus dihentikan segera, bila tidak, industri e-commerce akan tumbuh secara lambat.

\section{Edukasi dalam menumbuhkan kepercayaan konsumen}

Kepercayaan dari konsumen masih membutuhkan proses edukasi lebih lanjut. Salah satu solusinya adalah dengan menjalin kerjasama dengan media untuk menjelaskan pemahaman lebih baik tentang model bisnis e-commerce untuk menambah kepercayaan masyarakat.

\section{Kepercayaan pelanggan lebih berharga ketimbang sertifikasi}

Masalah lain yang menjadi sorotan adalah bagaimana menanamkan kepercayaan. Beberapa pemain ecommerce menekankan keharusan sertifikasi, sementara sisanya lebih mengutamakakan kepercayaan pelanggan.

\section{E-commerce akan dihilangkan dari daftar investasi berstigma negatif secara bertahap}

Sejak Juni 2013, e-commerce menjadi satu dari industri yang dicoret dari daftar investasi asing.

\section{Dukungan dan perlindungan bagi para pemain baru}

Kurangnya Pemerintah memberi kemudahan bagi para pendatang baru yang mau memasuki memasuki ranah ini.

\section{Solusi Pemecahan Masalah :}

1. Pemerintah harus mengambil langkah dalam menyelesaikan masalah infrastruktur internet yang belum stabil dan transportasi yang kerap sulit diandalkan. Prosedur perizinan dari bea cukai untuk pengantaran ke negara lain perlu ditingkatkan efisiensinya.

2. Pemerintah harus mempermudah aturan untuk layanan e-payment yang hingga saat ini masih berada di bawah peraturan yang sama dengan bank.

3. Pemerintah harus turut serta memberi pemahaman kepada masyarakat tentang keamanan bertransaksi online.

4. Pemerintah harus merencanakan dan melakukan pengenalan sistem sertifikasi.

5. Sejumlah pemain besar seharusnya bisa membuka jalan masuknya investasi asing, termasuk melakukan beberapa rencana besar mengenai investor asing, tentunya dengan peraturan yang jelas.

6. Pemerintah harus memberi kemudahan peraturan bagi bisnis kecil dan menengah untuk mendapatkan akses ke investor, dan memberi potongan pajak pada perusahaan baru.

Kesimpulan : 
1. Pertumbuhan e-commerce di dunia termasuk di Indonesia yang pesat, menuntut Pemerintah menyiapkan strategi yang efektif bagi otoritas perpajakan dalam menyikapinya. Salah satu hal yang perlu menjadi perhatian adalah perlu dijaga agar tidak terjadi distorsi sebagai akibat kebijakan perpajakan. Selama ini, aspek perpajakan dalam e-commerce telah menjadi sorotan otoritas perpajakan di dunia, terutama apakah harus ada pengenaan pajak baru terhadap transaksi ini dan juga bagaimana menyelaraskan peraturan perpajakan yang ada dengan perkembangan e-commerce.

2. Transaksi melalui media digital atau e-commerce di Indonesia perlu pembenahan dari sisi perundangan (CyberLaw) agar di kemudian hari tidak tejadi perselisihan dalam menjalankannya. Hal ini terjadi karena sulitnya melacak transaksi yang digunakan lewat e-commerece baik itu $\mathrm{B}$-to-B (bisnis ke bisnis) atau $\mathrm{B}$ to-C (bisnis to konsumen). Misalnya hubungan antara pemasok dengan pabrik, bagaimana aparat mengawasi telah ada transaksi atau belum antar keduanya lewat e-commerce tersebut

3. Solusi Pemecahan Masalahnya adalah Pemerintah harus mengambil langkah dalam menyelesaikan masalah infrastruktur internet yang belum stabil dan transportasi yang kerap sulit diandalkan, prosedur perizinan dari bea cukai untuk pengantaran ke negara lain perlu ditingkatkan efisiensinya, mempermudah aturan untuk layanan e-payment yang hingga saat ini masih berada di bawah peraturan yang sama dengan bank, memberi pemahaman kepada masyarakat tentang keamanan bertransaksi online, merencanakan dan melakukan pengenalan sistem sertifikasi, sejumlah pemain besar seharusnya bisa membuka jalan masuknya investasi asing, termasuk melakukan beberapa rencana besar mengenai investor asing, tentunya dengan peraturan yang jelas serta Pemerintah harus memberi kemudahan peraturan bagi bisnis kecil dan menengah untuk mendapatkan akses ke investor, dan memberi potongan pajak pada perusahaan baru.

\section{Referensi}

Efraim Turban, Linda Volonino. Information Technology for Management $7^{\text {th }}$ Edition. Wiley Plus,2007.

Nufransa Wira Sakti, Perpajakan Dalam e- Commerce, Belajar dari Jepang dari Berita Pajak No. 1443/Tahun XXXIII/15 Mei 2001

State and Local Government Sales Tax Revenue Losses from Electronic Commerce," by Donald Bruce, William F. Fox, and LeAnn Luna, State Tax Notes 52(7):537-558, May 18, 2009.

UU Perpajakan perpajakan nomor No. 9 Tahun 1994 Tentang Perubahan Atas 1994 Tentang Perubahan Atas Undang- Udang Nomor 6 Tahun 1983 Tentang Ketentuan Umum Dan Tata Cara Perpajakan

http://wartawarga.gunadarma.ac.id/2010/06/makalah-e-commerce/, diakses pada tanggal 16 Januari 2012

http://vially20.wordpress.com/makalah-e-commerce/diakses pada tanggal 16 Januari 2012

http://direktif.web.id/blog/arc/2006/09/ecommerce-atau-gerai-maya

http://id.shvoong.com/internet-and-technologies/1772238-e-commerce-untuk-usaha-anda/ 